\title{
IMPLEMENTASI NILAI MUSYAWARAH PADA PANCASILA MELALUI METODE DISKUSI KELAS DALAM PEMBELAJARAN PPKN KELAS IX DI SMP NEGERI 3 KRIAN SIDOARJO
}

\author{
Suhartono \\ Universitas PGRI Adi Buana Surabaya \\ suhartono@unipasby.ac.id
}

\begin{abstract}
ABSTRAK
Pancasila merupakan pandangan hidup bangsa Indonesia, terdiri atas lima sila. Nilai musyawarah adalah salah satu nilai yang terkandung dalam sila Pancasila. Metode diskusi kelas merupakan salah satu metode pembelajaran yang akrab digunakan siswa untuk mengungkapkan pendapat dalam kegiatan pembelajaran. Penelitian yang dilakukan di kelas IX SMP Negeri 3 Krian menghasilkan untuk menentukan nilai musyawarah di Pancasila, yang dapat diimplementasikan dalam metode diskusi kelas. Adapun untuk menentukan hambatan implementasi nilai-nilai pertimbangan dalam metode diskusi kelas, serta untuk menentukan hambatan implementasi nilai-nilai pertimbangan dalam metode diskusi. Peneliti dalam penelitian ini menggunakan pendekatan kualitatif. Teknik pengumpulan data menggunakan wawancara, observasi, angket, dan dokumentasi (metode diskusi kelas). Teknik analisis data menggunakan reduksi data, penyajian data, dan mendapatkan kesimpulan. Hasil penelitian ada enam pertimbangan musyawarah yang bisa diimplementasikan seperti mengutamakan kepentingan publik, tidak memaksakan memaksakan, keluarga baik hati memacu, berdasarkan tanggung jawab, patuh aturan, punya rasa tanggung jawab tuhan. Prosedur atau langkah implementasi nilai musyawarah dalam metode diskusi kelas seperti: berbagi tugas, memilih sumber masalah, siswa cerdas, reaksi sumber masalah dan kesimpulan pingsan implementasi dalam metode diskusi kelas seperti, siswa bot, pasif siswa, siswa memaksakan keinginan mereka, siswa menaruh minat pada yang pertama.
\end{abstract}

Katakunci : pancasila, nilai musyawarah, metode diskusi kelas

\section{ABSTRACT}

Pancasila constitute of the view of life of the Indonesian nation, consist of five precept. The value of deliberation is one of the values contained in the precepts of Pancasila. Discussion class methods one of the learning method that familiar students to express opinion in learning activities. The done research in class IX SMP Negeri 3 Krian produce to determine the value of deliberation in the Pancasila, which can be implemented in discussion class method. As to determine barriers of the implementation the values of the deliberation in the discussion class method, as to determine barriers of the implementation of the values of the deliberation in the discussion method. The researcher in this research used qualitative approach. Data collecting technique used interview, observation, questionnaire, anddocumentation (discussion class method). The data analyze technique used data reduction, data presentation, and get conclusion. The results of the research there are six deliberation valuecan be implementation such as puthny theinterest of the public, do not force the impose, kind families spirt, based on the responsibility, obey the rules, have sense of responsibility of god. Procedure or step to implementation deliberation value in discussion class method such as : share the task, choose the source of the problem, intelligent students, reaction the source of problem and conclusion blacked of the implementation in discussion class method such as, bot students, passive students, the student force their desire the students puthing their interest at the first.

Keywords : pancasila, value of deliberation, class discussion method 


\section{PENDAHULUAN}

Bentuk-bentuk Negara secara umum dapat siswa ketahui dengan melihat sisi pelaksanaan Negara atau yang lazim disebut sisi mekanisme Negara, yang nantinya Negara akan terbagi menjadi beberapa bentuk diantaranya monarki, oligarki dan demokrasi (Yasin, 2016). Dari bentukbentuk Negara tersebut terdapat kekhasan yang berbeda, sehingga mudah untuk mengerti serta dipahami oleh masyarakat atau siswa yang sedang mempelajarinya. Seperti monarki dengan ciri khas pelaksanaannya layaknya sebuah kerajaan, oligarki bercirikan sebuah negara yang pelaksanaannya dijalankan oleh beberapa orang yang berkuasa, sedangkan Negara demokrasi yang bercirikan suatu negara yang kedaulatan tertingginya ditangan rakyat.

Negara Indonesia adalah negara yang juga memiliki identitas dengan ciri khas keanekaragaman masyakat yang ada didalamnya (Rahayu: 2017). Masyarakat Indonesia sangat banyak memiliki perbedaan (heterogen), diantaranya berbeda keyakinan terhadap Tuhan YME (agama), perbedaan suku, perbedaan ras, perbedaan adat istiadat bahkan perbedaan budaya membalut kehidupan masyarakat yang ada didalamnya. Namun demikian banyaknya perbedaan didalam Indonesia tidak lantas membuat mereka bercerai-berai, akan tetapi perbedaan itu membangun suatu ikatan batin dengan semboyan Bhineka Tunggal lka yang memiliki filosofi arti meskipun berbeda-beda tetapi tetap satu jua. Bentuk Negara Indonesia ialah demokrasi dan menganut sistem pemerintahan presidensial, dengan keanekaragaman yang dimiliki oleh Indonesia menjadikan Indonesia sangat pas apabila mekanisme pelaksanaan negaranya berbentuk demokrasi. Bentuk negara demokrasi sangat identik dengan kedaulatan rakyat dan juga penyelesaian masalah melalui musyawarah untuk mufakat.

Musyawarah untuk mufakat menjadi ciri khas yang dimiliki oleh negara Indonesia, hal sesuai dengan bentuk masyarakat negara Indonesia yang beranekaragam, serta sejalan dengan cita-cita para pendiri bangsa. Musyawarah tidak hanya cita-cita para pendiri bangsa saja, namun juga termuat didalam dasar Negara Republik Indonesia terutama pada sila keempat yang menjunjung tinggi musyawarah dalam penyelesaian suatu masalah (Kansil: 2011). Masyarakat Indonesia yang heterogen dianjurkan menempuh jalan musyawarah dalam penyelesaian suatu permasalahan juga dalam hal pengambilan suatu keputusan, dengan cara musyawarah ini maka semua pendapat warga dari agama, ras, suku, serta golongan yang berbeda dapat terwadahi.

Musyawarah suatu budaya dan ciri khas yang dimiliki oleh bangsa Indonesia, namun di era saat ini (Era 
Globalisasi dan Industri 4.0) budaya serta ciri khas tersebut tidak lagi membanggakan di Indonesia. Tujuan dilakukan suatu musyawarah itu untuk bersama-sama mencapai kata mufakat dalam pengambilan keputusan dalam penyelesaian masalah (Rahayu: 2017), namun tujuan itu tidak lagi seperti itu. Karena dalam pengambilan keputusan dalam penyelesaian masalah yang ada di Indonesia saat ini telah bergeser dengan melakukan voting dari pada bermusyawarah mendengarkan pendapat dari peserta-peserta rapat yang terlibat.

Pergeseran budaya

musyawarah itu tidak hanya terjadi dilingkungan masyarakat saja, akan tetapi juga terjadi di sector pemerintahan (Detiknews: 2017). Pemerintahan negara Indonesia yang seharusnya menjadi sarana aspirasi rakyat melalui wakil-wakil nya yang telah dipilih didalam kursi-kursi wakil rakyat seperti DPR, dalam pengambilan keputusan untuk suatu kebijakan mereka jarang menyelesaikannya dengan musyawarah namun lebih sering menggunakan voting (berdasarkan suara terbanyak).

Agenda yang dimiliki oleh wakilwakil rakyat memiliki penyebutan rapat bertujuan untuk mencari keputusan berdasarkan mufakat (Yuwanto: 2016) kenyataanya didalam pelaksanaan rapat-rapat DPR sering diterapkan pengambilan keputusan berdasarkan suara terbanyak/voting. Meski terkadang memang diterapkan musyawarah untuk mufakat dalam rapat anggota DPR namun dalam pelaksanannya kurang begitu baik. Rapat yang dilakukan sering kali menyimpang tidak sesuai dengan nilai-nilai musyawarah sebenarnya.

Perilaku menyimpang terhadap nilai-nilai dalam musyawarah sering dipertontonkan para anggota DPR dalam rapat. Salah satu agenda rapat yang memperlihatkan perilaku menyimpang dari nilai-nilai musyawarah oleh para anggota DPR, sebagai contoh dalam pelaksanaan rapat paripurna hak angket KPK yang berakhir dengan ricuh, ada tindakan walk out sebagian anggota dewan yang kurang setuju dengan keputusan rapat tersebut (Kompas: 2017). Contoh tersebut bentuk perilaku yang tidak sesuai dengan nilai-nilai dalam musyawarah.

Banyaknya perilaku menyimpang dari budaya bangsa Indonesia yaitu dalam bermusyawarah dalam penyelesaian masalah, pembenahan dapat dimulai dari bidang pendidikan. Dengan Pendidikan para penerus bangsa yang baik dilahirkan. Penerapan nilai-nilai musyawarah yang baik dapat ditanamkan dan diterapkan melalui metode-metode pembelajaran oleh guru dalam pelaksanaan pembelajaran di sekolah, seperti penerapan metode diskusi kelas dalam kegiatan pembelajaran (Majid: 2014). 
Setiap guru dapat menentukan metode-metode pembelajaran masing-masing yang dapat diterapkan dan disesuaikan dalam pembelajaran yang akan dilakukan. Realisasi kurikulum 2013 dengan ciri pembelajaran yang menonjolkan aktivitas dan kreativitas, menginspirasi, dan berpusat pada siswa. Kondisi semacam itulah yang melatarbelakangi penelitian melakukan penelitian di sekolah, sekolah telah menerapkan kurikulum 2013. Diantara banyak metodemetode pembelajaran, metode diskusi kelas adalah salah satu metode pembelajaran yang cocok diterapkan pada sekolah dalam Kegiatan pengimplementasian nilai musyawarah yang ada pada salah satu sila Pancasila. Melalui metode diskusi kelas sesuai dengan kurikulum yang direalisasikan oleh pemerintah sehingga dapat diimplementasikan di sekolah dalam proses pembelajaran (Kemendikbud: 2019).

\section{METODE PENELITIAN}

Metode yang digunakan dalam penelitian ini adalah pendekatan kualitatif dalam bentuk penelitian deskriptif. (Sugiyono: 2015) Teknik pengumpulan data menggunakan teknik wawancara, observasi dan angket serta didukung dengan dokumentasi berupa foto-foto kegiatan pengimplementasian nilai musyawarah. (Arikunto: 2013)

Peneliti dalam penelitian ini mencari data berupa nilai musyawarah pada Pancasila yang dapat diimplementasikan. Data tentang cara pengimplementasian nilai musyawarah pada Pancasila melalui metode diskusi kelas, dan hambatan-hambatan yang ada pada pengimplementasian nilai musyawarah yang terdapat pada Pancasila melalui metode diskusi kelas. Data-data tersebut diperoleh dari sumber data diantaranya: Waka Kurikulum SMPN 3 Krian, Guru mata pelajaran PPKn di SMPN 3 Krian, dan siswa kelas IX C serta IX D. Teknik analisis data yang digunakan untuk menganalisis data-data yang telah didapat pada penelitian ini adalah teknik analisis yang dikemukakan oleh Huberman dan Miles (2002) seperti: Data Reduction (Penyederhanaan data), Penyajian Data (Display Data), dan Tahap Penarikan Kesimpulan (Conclusion Drawing/ Verification). Sedangkan untuk teknik pengecekan keabsahan data peneliti menggunakan teknik triangulasi yang terdiri dari : triangulasi sumber, triangulasi teknik, dan triangulasi waktu (Sugiyono: 2015).

\section{HASIL PENELITIAN DAN} PEMBAHASAN

Agar dapat diketahui data tentang nilai-nilai musyawarah pada Pancasila yang dapat diimplementasikan melalui metode diskusi kelas, maka peneliti penggunakan teknik pengumpulan data : a) Teknik wawancara pada guru matapelajaran. b) Teknik angket pada 
Waka Kurikulum SMPN 3 Krian. Dari kedua teknik yang digunakan oleh peneliti dan pada sumber data yang berbeda memiliki hasil bahwa nilai musyawarah pada Pancasila yang dapat diimplementasikan adalah sebagai berikut: 1. Mendahulukan kepentingan umum saat bermusyawarah $2 . \quad$ Tidak memaksakan kehendak saat memberikan pendapat, 3. munculnya semangat kekeluargaan saat bermusyawarah, 4. Munculnya rasa tanggungjawab saat mengutarakan pendapat dalam musyawarah 5 . Dalam penyampaian pendapat harus memperhatikan aturan-aturan yang ada dalam musyawarah, 6 . Keputusan yang dihasilkan dalam musyawarah harus di pertanggungjawabkan kepada Tuhan Yang Maha Esa.

Setelah mengetahui nilai-nilai musyawarah yang dapat diimplementasikan melalui metode diskusi kelas, selanjutnya peneliti mencari data bagimana cara pengimplementasiannya pada sumber-sumber data. Peneliti menggunakan tiga teknik dan tiga sumber data untuk mengetahui cara pengimplementasiannya sebagai berikut : a) Teknik observasi digunakan oleh peneliti pada sumber data guru matapelajaran PPKn melalui observasi. b) Teknik Angket yang digunakan oleh peneliti pada siswa kelas IX C untuk mengetahui keberhasilan pengimplementasian. c)Teknik Wawancara yang digunakan pada sumber data DN (inisial perwakilan siswa kelas IX D) untuk mengetahui tingkat keberhasilan pengimplementasian. Dari kegiatan pengumpulan data yang telah dilakukan oleh peneliti maka mendapat hasil sebagai berikut: 1 . Adanya pembagian tugas pelaksana dalam diskusi seperti moderator, narasumber dan notulen, 2. Pemilihan sumber masalah yang dapat dibahas. Pada diskusi ini sumber masalah telah disediakan oleh guru, 3.Siswa menanggapi pendapat peserta lain dalam diskusi, 4. Tanggapan dari Guru, 5. Menyimpulkan hasil diskusi.

Pengimplementasian nilai-nilai musyawarah pada Pancasila melalui metode diskusi kelas tentu saja memilki beberapa hambatan (Suyahmo, 2015). Untuk mengetahui hambatan-hambatan yang muncul maka dalam penelitian ini peneliti menggunakan dua teknik pengumpulan data dan dua sumber data sebagai berikut : a) Guru mata pelajaran PPKn di SMPN 3 Krian dengan teknik wawancara. b) Waka Kurikulum SMPN 3 Krian dengan teknik angket. Dari kedua sumber data dengan teknik pengumpulan data yang berbeda diperoleh data sebagai berikut: 1 . Adanya siswa yang menonjol namun tidak memberikan kesempatan pada siswa lain, 2. Ada beberapa siswa yang pasif dalam kegiatan diskusi, 3. Siswa masih ada yang memaksakan kehendak dalam diskusi, 4. Siswa mementingkan kepentingan pribadi. 


\section{SIMPULAN}

Kesimpulan dalam penelitian ini ialah terdapat enam nilai musyawarah yang dapat diimplentasikan, terdapat lima cara pengimplementasian nilainilai musyawarah tersebut melalui metode diskusi kelas dan terdapat empat hambatan dalam pengimplementasian nilai musyawarah pada Pancasila melalui metode diskusi kelas, maka penjabarannya sebagai berikut :

1. Nilai-Nilai Musyawarah Pada Pancasila yang Dapat Diimplementasikan Melalui Metode Diskusi Kelas

Senantiasa mendahulukan kepentingan umum dalam musyawarah, tidak tiperkenankan memaksakan kehendak dalam penyampaian pendapat, adanya semangat kekeluargaan dalam kegiatan musyawarah, dalam penyampaian pendapat dilandasi dengan penuh rasa tanggungjawab, dalam penyampaian pendapat harus memperhatikan aturan-aturan yang sudah diterapkan dalam musyawarah, segala pendapat dan keputusan bersama hasil musyawarah harus di pertanggungjawabkan kepada Tuhan Yang Maha Esa.

2. Cara Pengimplementasian Nilai Musyawarah Pada Pancasila Melalui Metode Diskusi Kelas Adanya pembagian tugas dalam diskusi seperti moderator, narasumber dan notulen, pemilihan sumber permaslahan yang akan dibahas. Pada diskusi ini sumber masalah diwakili oleh guru, siswa menanggapi pendapat siswa lain yang disampaikan dalam diskusi, tanggapan dari sumber masalah (guru), dengan kesepakatan menyimpulkan hasil diskusi secara bersama-sama.

3. Hambatan-Hambatan

Pengimplementasian Nilai Musyawarah Pada Pancasila Melalui Metode Diskusi Kelas Ada siswa yang menonjol yang tidak memberikan kesempatan kepada siswa lain, Ada juga siswa yang pasif dalam kegiatan diskusi, siswa yang masih memaksakan kehendaknya dalam diskusi, Adanya siswa yang mementingkan kepentingan pribadi dalam berdiskusi.

\section{DAFTAR PUSTAKA}

Arikunto, Suharsimi. 2013. Prosedur Penelitian. Jakarta: Rineka Cipta

Detiknews. $\quad 30 \quad$ September 2017. "Masyarakat RI Dinilai Menjauh dari Musyawarah Mufakat". Jakarta. Diakses pada 29 Januari 2019. https://www.detik.com/tag/mus yawarah

Huberman, M., \& Miles, M. B. 2002. The qualitative researcher's companion. Sage.

Kansil. 2011. Empat Pilar Berbangsa dan Bernegara. Jakarta : P.T. Rineka Cipta

Kemendikbud. 2019. Data Pokok Pendidikan Dasar dan Menengah 


\section{Direktorat Jendral Pendidikan Dasar dan Menengah. http://dapo.dikdasmen.kemdikb ud.go.id/sekolah/906CC3268C61 C39C0D63. dikunjungi 15 Januari $\underline{2019}$}

Kompas. 2017 Rapat Paripurna Hak Angket KPK Ricuh Sejumlah Anggota DPR Walk Out: Edisi Jum'at, 28 April 2017. Diakses pada 05 Desember 2018. https://nasional.kompas.com , News > Nasional

Majid. A. 2014. Strategi Pembelajaran. Bandung: PT Remaja Rosdakarya

Rahayu, A.S. 2017. Pendidikan Pancasila dan Kewarganegaraan (PPKn). Jakarta: PT Bumi Aksara

Sugiyono, 2015. Metodologi Penelitian Kuantitatif Kualitatif dan $R \& D$, Bandung: Alfabeta.

Suyahmo. 2015. Model Implementasi Sila Ke-4 Kerakyatan yang Dipimpin oleh Hikamat Kebijaksanaan dalam Permusyawaratan/Perwakilan. Jurnal Penelitian Pendidikan Vol. 32 No.1. Diakses pada 14 Agustus 2018.

https://journal.unnes.ac.id/nju/i ndex.php/JPP/article/download/ $\underline{5707 / 4579}$

Yasin, R. 2016. Telaah Putusan MK dalam Sengketa PHPU Pilpres 2004 (Perspektif Negara Demokrasi Konstitusional). Jurnal Konstitusi, 11(4), 650-670.

Yuwanto. 2016. Parlemen dan Demokratisasi: Peran Dewan Perwakilan Rakyat Dalam Transisi Demokrasi Di Indonesia. Jurnal Ilmiah Ilmu Pemerintahan,
Vol 2 No. 2 Maret 2016. Diakses pada 10 Januari 2019. https://ejournal2.undip.ac.id/in dex.php/iiip/article/download/2 $\underline{121 / 1352}$ 